\title{
Hubungan Tingkat Pengetahuan Dengan Sikap Keluarga Penderita Demam Berdarah Dengue Tentang Pemberantasan Sarang Nyamuk (PSN) Di Wilayah Kerja Puskesmas Curahdami
}

\author{
Riska Dewi Dian Susanti ${ }^{1}$, Hefniy ${ }^{2}$, Yuana Dwi \\ Agustin $^{3}$, Setyo Adi Nugroho4 \\ 1. Dinas kesehatan Bondowoso, \\ Email: sasi.kirana.luchu@gmail.com \\ 2. Universitas Nurul Jadid, \\ Email: hefniyrz@gmail.com \\ 3. RSUD dr H. Koesnadi Bondowoso \\ email: yuanadwi1975@gmail.com \\ 4. Universitas Nurul Jadid, \\ Email: setiyo666@gmail.com
}

\section{Abstract}

Dengue Hemorrhagic Fever (DHF) is also one of the infectious diseases that often cause extraordinary events. Low awareness to maintain environmental cleanliness and lack of public knowledge about eradicating mosquito nests to prevent Dengue Hemorrhagic Fever. This study aims to identify the relationship between the level of knowledge and the family attitudes of dengue hemorrhagic fever sufferers regarding the eradication of mosquito nests (PSN) in the work area of the Curahdami Health Center in Bondowoso Regency.Types of quantitative research designs. population and sample of 37 respondents by using total sampling. Data collection techniques used the Likert scale questionnaire to measure Knowledge Level and bivariate analysis was performed to determine the relationship between variables using Spearman's Rho. 
Statistical test results of Spearman's Rho. Obtained p-value 0.002 which means that Ho is rejected and $H 1$ is accepted. There is a relationship between the level of knowledge with the family attitudes of dengue hemorrhagic fever sufferers about the eradication of mosquito nets in the work area of the bulk health center with a correlation coefficient of 0.487.From the results of this study, the level of knowledge of families suffering from dengue fever in eradicating mosquito nests in the Bondowoso district health center area is good.

Keywords: Knowledge Level, Attitude, Dengue Hemorrhagic Fever, Eradication of Mosquito Nests

\section{Abstrak}

Penyakit Demam Berdarah Dengue juga merupakan salah satu penyakit menular yang sering menimbulkan kejadian luar biasa. Rendahnya kesadaran untuk menjaga kebersihan lingkungan dan pengetahuan masyarakat yang kurang tentang pemberantasan sarang nyamuk untuk mencegah penyakit Demam Berdarah Dengue. Penelitian ini bertujuan untuk mengidentifikasi Hubungan Tingkat Pengetahuan Dengan Sikap Keluarga Penderita Demam Berdarah Dengue Tentang Pemberantasan Sarang Nyamuk (PSN) Di Wilayah Kerja Puskesmas Curahdami Kabupaten Bondowoso. Jenis rancangan penelitian kuantitatif. populasi dan sampel sebanyak 37 responden.dengan menggunakan total sampling. Tekhnik pengumpulan data menggunakan kuesioner skala likert untuk mengukur Tingkat Pengetahuan dan dilakukan Analisis bivariat untuk mengetahui hubungan 
antara variabel menggunakan Spearman's Rho. Hasil uji statistik Spearman's Rho. Didapatkan $p$ value 0,002 yang berarti Ho ditolak dan $\mathrm{H} 1$ diterima maka, Ada Hubungan Tingkat Pengetahuan Dengan Sikap Keluarga Penderita Demam Berdarah Dengue Tentang Pemberantasan Sarang Nyamuk Di Wilayah Kerja Puskesmas Curahdami dengan tingkat Correlation Coefficient 0,487. Dari hasil penelitian ini menunjukkan tingkat pengetahuan keluarga penederita demam berdrah dengue tentang pemberantasan sarang nyamuk di wilayah puskesmas curahdami kabupaten bondowoso adalah baik.

Kata Kunci: Tingkat Pengetahuan, Sikap, Demam Berdarah Dengue, Pemberantasan Sarang Nyamuk. 


\section{Pendahuluan}

Tingkat curah hujan dan kelembapan yang tinggi di Indonesia merupakan salah satu faktor yang mengakibatkan perkembangan dari sumber penyakit. Banyak penyakit yang dapat terjadi pada saat musim penghujan yaitu salah satunya adalah penyakit Demam Berdarah Dengue (DBD) (Djunaedi D, 2006). Penyakit DBD cenderung meningkat setiap tahunnya, penyakit ini telah menyerang hampir seluruh kota atau daerah di Indonesia dan jumlah penderitanya cukup tinggi bahkan sampai menimbulkan kematian. Jutaan kasus infeksi Demam Berdarah Dengue terjadi setiap tahunnya di seluruh dunia." Dalam beberapa tahun terakhir, penyakit ini meningkat insidennya diberbagai belahan dunia terutama daerah tropis dan subtropis, banyak ditemukan diwilayah urban dan semiurban. Penyakit ini ditularkan melalui gigitan nyamuk Aedes yang mengandung virus dengue. (Kemenkes,
2017). Nyamuk Aedes menggigit penderita DBD kemudian ditularkan kepada orang sehat. Masa menggigitnya yang aktif ialah pada awal pagi yaitu dari pukul 09.00-10.00 WIB dan pukul 16.0017.00 WIB (Kemenkes, 2017). Nyamuk Aedes ini berkembang biak ditempa tempat penampungan air atau tandon, seperti bak kamar mandi, drum, tempayan, dan barang bekas yang dapat menampung air hujan baik dirumah, sekolah dan tempat umum lainnya (Kemenkes, 2017) Dibutuhkan dukungan peran serta petugas kesehatan dan masyarakat dalam memperbaiki kesehatan lingkungan di sekitar rumah agar tidak menjadi tempat bersarangnya nyamuk Aedes dan melaksanakan kegiatan Pemberantasan Sarang Nyamuk Aedes Aegypti dengan baik.

Penyakit DBD juga
merupakan salah satu
penyakit menular yang
sering menimbulkan
kejadian luar biasa. Hal ini
menunjukkan bahwa sulit
sekali menghentikan


transmisi penyakit ini karena banyak faktor yang berperan dalam dinamika penularan penyakit Demam Berdarah Dengue yang mencakup interaksi Host-Agent-Environment (Kemenkes, 2017)

Sampai saat ini masih belum ditemukan obat dan vaksin yang efektif untuk penyakit Demam Berdarah Dengue. Mengingat sangat berbahayanya penyakit DBD (Kemenkes, 2017). maka perlu ada upaya pemberantasan yang komprehensif dari penyakit

tersebut.Pemerintah telah mengeluarkan kebijakan Pemberantasan Sarang Nyamuk (PSN 3M-Plus) untuk menanggulangi penyakit DBD. Ini merupakan cara utama yang di anggap efektif, efisien dan ekonomis untuk memberantas vector penular DBD.

Dari

penelitian

beberapa yang menghubungkan karakteristik individu, pengetahuan, sikap dengan tindakan pencegahan DBD, yaitu: Utami (2010) dengan judul penelitian hubungan tingkat pendidikan formal terhadap perilkau pencehagan demam berdarah dengue pada masyarakat dikelurahan Bekonang, Sukoharjo. Dengan hasil penelitiannya yaitu tingkat pendidikan formal memiliki hubungan dengan perilaku pencegahan

DBD.Dikatakan tinggi tingkat pendidikan seseorang maka biasanya tingkat kepedulian terhadap kesehatan diri dan lingkungan semakin baik (Larasati, 2013) (Utami, 2010) Riyanto dengan judul penelitian hubungan tingkat pendidikan,pengetahuan dan sikap ibu rumah tangga dengan kegiatan $3 \mathrm{M}$ demam berdarah dengue di Puskesmas Loa Ipuh Kabupaten Kutai Kartanegara. Dengan hasil penelitiannya yaitu ada hubungan yang signifikan antara tingkat pendidikan,pengetahuan dan sikap dengan kegiatan 3M DBD (Riyanto, 2010) Berdasarkan data dari World Health Organization (WHO) mencatat. Di Asia Tenggara tercatat 15,2 juta kasus 
DBD terjadi pada tahun 2018. Sementara Indonesia dilaporkan sebagai Negara ke dua dengan kasus DBD terbesar di antara 30 negara wilayah endemis (Rahayu et al, 2017)

Dalam profil kesehatan Provinsi Jawa Timur, kecenderungan situasi DBD dari tahun 2017 - 2018 terlihat bahwa "kasus DBD ditemukan setiap tahun dan hampir selalu mengalami kenaikan kasus.Pada tahun 2015, DBD berjangkit di 463 Kabupaten/ kota dengan angka kesakitan sebesar 78,13 per 100.000 penduduk, namun angka kematian dapat ditekan 1 persen yaitu $0,79 \%$ (Kemenkes, 2017)

Berdasarkan data sementara yang dihimpun Kementrian Kesehatan dari awal tahun hingga 29 januari 2019,jumlah penderita DBD yang dilaporkan mencapai 13.683 orang di seluruh Indonesia. Jawa Timur menjadi Provinsi dengan kasus tertinggi, baik dari data januari 2018 maupun januari 2019. Pada tahun lalu kasus tertinggi terjadi dikota malang, sedangkan pada tahun ini yang tertinggi adalah Kabupaten Kediri. Jawa Timur merupakan salah satu daerah rawan, hal ini dapat dilihat dari angka kejadian kasus DBD yang terus meningkat.

Dari data kasus

DBD di Dinas Kesehatan Provinsi Jawa Timur, Kabupaten Bondowoso menduduki peringkat ke 25 dari 38 Kabupaten di Provinsi Jawa Timur. Kabupaten Bondowoso tidak termasuk kejadian luar biasa (KLB), karena tidak memenuhi syarat kriteria KLB yaitu di Kabupaten Bondowoso meskipun selalu ada kejadian DBD tetapi angka kejadiannya turun naik, tidak terjadi peningkatan kasus DBD secara drastis, dan angka kematian akibat DBD tidak sampai 50\%. Berdasarkan Data Dinas Kesehatan Kabupaten Bondowoso, jumlah kasus DBD di Kabupaten Bondowoso tahun 2018 sebesar 249 kasus, angka kesakitan sebesar 61,66\% per 100.000 penduduk dan angka kematian 6 penderita (Subdin P2PM, n.d. 2019)

Berdasarkan data dari Dinas Kesehatan 


\section{Riska Dewi Dian Susanti : Tingkat Pengetahuan}

Kabupaten Bondowoso pada tahun 2019 dari bulan januari sampai bulan februari tercatat 214 kasus Demam Berdarah Dengue (Subdin P2PM, 2019)

Sedangkan untuk kasus DBD sekecamatan di Kabupaten Bondowoso, Kecamatan Curahdami berada di peringkat pertama yaitu terdapat 33 kasus DBD di tahun 2018, dan di tahun 2019 bulan Januari - Maret tercatat 37 kasus (Subdin P2PM, 2019). Terjadi Peningkatan yang cukup signifikan dibandingkan dengan tahun 2018. Hal ini dikarenakan kemungkinan sanitasi yang buruk, rendahnya kesadaran untuk menjaga kebersihan lingkungan dan pengetahuan masyarakat yang kurang tentang pemberantasan sarang nyamuk untuk mencegah penyakit Demam Berdarah Dengue.

$\begin{array}{cc}\text { Menurut } & \text { konsep } \\ \text { Lawrence } & \text { Green, }\end{array}$
kesehatan seseorang atau masyarakat dipengaruhi faktor perilaku (behaviour causes) dan faktor diluar perilaku (non-behaviour causes). Faktor perilaku meliputi faktor terdisposisi (pengetahuan, sikap, kepercayaan), faktor pendukung (fasilitas pelayanan kesehatan), dan faktor pendorong (sikap dan perilaku petugas kesehatan). (Notoatmodjo, 2014). Keluarga yang memiliki pengetahuan yang baik mengenai Pemberantasan Sarang Nyamuk (PSN) yang benar ,bisa memutuskan sikap apa yang dapat dilakukan untuk mengatasi masalah kejadian Deman Berdarah Dengue (DBD). Peningkatan

terhadap pengetahuan tidak mutlak diperoleh dari pendidikan formal, akan tetapi juga dapat diperoleh pada pendidikan non formal. Pengetahuan seseorang tentang sesuatu objek juga mengandung dua aspek yaitu aspek positif dan negatif. Kedua aspek inilah yang akhirnya akan menentukan sikap seseorang terhadap objek tertentu. Semakin banyak aspek positif dari objek yang diketahui, akan menumbuhkan sikap yang semakin positif terhadap objek tersebut (Syahrani, Santoso, \& Sayono (2012) dalam ery wahyuni, 2015) 


Pengetahuan tidak
hanya diperoleh dari
bangku sekolah melainkan
dapat diperoleh dari mana
saja, yang paling penting
bagaimana pengetahuan
itu dapat memberikan
sikap yang baik bagi
seseorang.
Tingkat ini yang
pengetahuan ini
nantinya akan membentuk sikap seseorang terhadap sesuatu. Sikap belum merupakan suatu tindakan atau aktivitas, akan tetapi masih merupakan predisposisi tindakan suatu perilaku. Sikap seseorang akan mempengaruhi perilaku kesehatan, sikap positif seseorang akan menghasilkan perilaku kesehatan yang positif pula.

Perilaku sehat adalah pengetahuan, sikap, tindakan, proaktif untuk memelihara dan mencegah risiko terjadinya penyakit.Perilaku sehat terdiri dari perilaku pemeliharaan kesehatan, perilaku pencarian dan penggunaan fasilitas pelayanan kesehatan, serta perilaku kesehatan lingkungan.

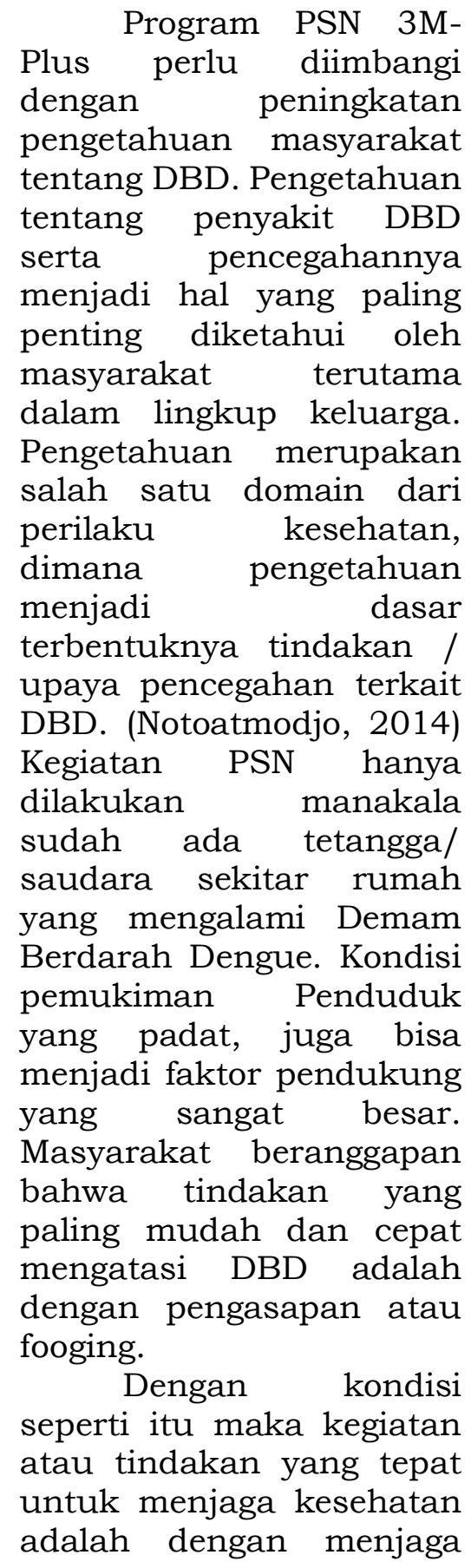




\section{Riska Dewi Dian Susanti : Tingkat Pengetahuan}

lingkungan tetap bersih dan terbebas dari nyamuk demam berdarah.Kegiatan untuk menjaga terbebas dari nyamuk demam berdarah yaitu dengan PSN yang idealnya kegiatan PSN tersebut dilakukan minimal 1 minggu sekali.

\section{Metode}

Jenis penelitian menggunakan metode korelasi dan observasi dengan pendekatan CrossSectional dengan tehnik Total Sampling. Alat ukur yang digunakan dalam penelitin ini adalah kuesioner

Analisa dilakukan secara univariat dan bivariat dengan menggunakan uji Spearman's Rho, nilai $\mathrm{p} \leq$ 0,05 berarti hasil perhitungan statistik bermakna (signifikan) atau menunjukkan ada hubungan antara variabel independen dengan variabel dependen.

\section{Hasil Penelitian}

Karakteristik

Pengetahuan

Pemberantasan

Nyamuk

Tingkat

Tentang

Sarang

Tabel 1 Karakteristik

Tingkat Pengetahuan
Tentang Pemberantasan Sarang Nyamuk

\begin{tabular}{ccc}
\hline $\begin{array}{c}\text { Tingkat } \\
\text { Pengehuan }\end{array}$ & Frekuensi & $\begin{array}{c}\text { Prosentas } \\
\text { e }\end{array}$ \\
\hline Kurang & 9 & $24,3 \%$ \\
Cukup & 9 & $24,3 \%$ \\
Baik & 19 & $51,4 \%$ \\
\hline Total & $\mathbf{3 7}$ & $\mathbf{1 0 0} \%$ \\
\hline
\end{tabular}

Sumber: Angket Penelitian Dari tabel 1 diatas menunjukkan bahwa Tingkat Pengetahuan Tentang Pemberantasan Sarang Nyamuk kurang sebanyak 9 responden $(24,3 \%)$, cukup sebanyak 9 responden $(24,3 \%)$ dan baik sebanyak 19 responden (51,4\%).

a. Karakteristik Sikap

Keluarga Penderita

Demam Berdarah

Dengue

Tabel 2 Karakteristik Sikap Keluarga Penderita Demam Berdarah Dengue

\begin{tabular}{ccc}
\hline $\begin{array}{c}\text { Sikap } \\
\text { Keluarga }\end{array}$ & Frekuensi & Prosentase \\
\hline Kurang & 7 & $18,9 \%$ \\
Cukup & 14 & $37,8 \%$ \\
Baik & 16 & $43,3 \%$ \\
\hline Total & $\mathbf{3 7}$ & $\mathbf{1 0 0} \%$ \\
\hline Sumber: Angket Penelitian \\
\multicolumn{3}{c}{ Dari tabel 2} \\
diatas menunjukkan \\
bahwa sikap keluarga \\
penderita & demam \\
berdarah dikategorikan
\end{tabular}




\section{Riska Dewi Dian Susanti : Tingkat Pengetahuan}

kurang sebanyak 7 responden $\quad(18,9 \%)$, cukup sebanyak 14 responden $(37,8 \%)$ dan baik sebanyak 16 responden $(43,3 \%)$.

b. Hubungan

Tingkat

Pengetahuan

Dengan

Sikap

Keluarga

Penderita

Demam

Berdarah

Dengue

Tentang

Pemberantasan Sarang

Nyamuk Di Wilayah

Kerja

Puskesmas

Curahdami

Tabel 3 Tabulasi Silang

Hubungan

Tingkat

Pengetahuan Dengan

Sikap Keluarga Penderita

Demam

Berdarah

Dengue

Tentang

Pemberantasan Sarang

Nyamuk Di Wilayah Kerja

Puskesmas Curahdami

\begin{tabular}{|c|c|c|c|c|c|c|c|c|}
\hline \multirow{3}{*}{$\begin{array}{c}\text { Tingkat } \\
\text { Pengetahuan } \\
\text { Demam Berdarah } \\
\text { Dengue }\end{array}$} & \multicolumn{6}{|c|}{$\begin{array}{c}\text { Sikap Keluarga Penderita Demam Berdarah } \\
\text { Dengue }\end{array}$} & \multirow{3}{*}{\multicolumn{2}{|c|}{ TOTAL }} \\
\hline & \multicolumn{2}{|c|}{ Kurang } & \multicolumn{2}{|c|}{ Cukup } & \multicolumn{2}{|c|}{ Baik } & & \\
\hline & F & $\%$ & F & $\%$ & $\mathbf{F}$ & $\%$ & & \\
\hline Kurang & 5 & $13,5 \%$ & 4 & $10,8 \%$ & 0 & $0,0 \%$ & 9 & $24,3 \%$ \\
\hline Cukup & 2 & $5,4 \%$ & 1 & $2,7 \%$ & 6 & $16,2 \%$ & 9 & $24,3 \%$ \\
\hline Baik & 0 & $0,0 \%$ & 9 & $24,3 \%$ & 10 & $27,0 \%$ & 19 & $51,4 \%$ \\
\hline Total & 7 & $18,9 \%$ & 14 & $37,8 \%$ & 16 & $43,2 \%$ & 37 & $100,0 \%$ \\
\hline P Value 0,002 & & $\alpha=0,05$ & & & Corre & lation Coef & icien & 487 \\
\hline
\end{tabular}

Sumber : Angket Penelitian

Uji statistik

Spearman's Rho dengan

derajat kemaknaan $p \leq$

0,05. Didapatkan $p$

value 0,002 yang

berarti Ho ditolak dan
H1 diterima maka, Ada

Hubungan

Tingkat

Pengetahuan Dengan

Sikap

Keluarga

Penderita

Demam

Berdarah

Dengue

Tentang

Pemberantasan Sarang Nyamuk Di Wilayah Kerja Puskesmas Curahdami dengan tingkat Correlation Coefficient 0,487.

\section{Pembahasan}

a. Tingkat Pengetahuan Pemberantasan Sarang Nyamuk

Untuk lebih mendalami analisis mengenai tingkat pengetahuan responden maka dilakukan observasi terhadap tingkat pengetahuan secara spesifik berdasarkan pertanyaan tentang pengetahuan yang dijawab oleh responden. Hasilnya adalah secara umum responden telah mengetahui hal - hal yang berhubungan dengan penyakit DBD dan kegiatan PSN. Responden sudah mengetahui hal-hal yang berhubungan dengan 3M (menguras, 


\section{Riska Dewi Dian Susanti : Tingkat Pengetahuan}

\begin{tabular}{|c|c|}
\hline $\begin{array}{l}\text { menutup } \\
\text { mengubur). }\end{array}$ & $\begin{array}{l}\text { memiliki pendidikan } \mathrm{SD} \\
\text { atau sederajat lebih }\end{array}$ \\
\hline Pengetahuan & dominan memili \\
\hline masih kurang terlihat & pengetahuan \\
\hline pengetahuan & kurang \\
\hline tentang kejadian DBD & Sejalan \\
\hline (penyebab dan vektor) & Penelitian \\
\hline serta pengetahuan & dilakukan oleh Syed \\
\hline ntang gejala penyakit & Saleem, $\quad(201$ \\
\hline D. & menemukan bahwa d \\
\hline Menurut & 400 responden \\
\hline angevelt bahwa & laki-laki, \\
\hline endidikan & perempuan) ditemuk \\
\hline latu proses membawa & bahwa $35 \%$ respond \\
\hline lanusia ke arah & mempunyai \\
\hline edewasan. Pendapat & pengetahuan \\
\hline in adalah Crow dan & adekuat tentang DE \\
\hline row yang menyatakan & dan vektor DBD (Sye \\
\hline pendidikan & 2010) Dan H \\
\hline dalah proses dimana & penelitian \\
\hline engalaman & sesuai dengan peneliti \\
\hline $\begin{array}{l}\text { formasi di peroleh dari } \\
\text { elajar. }\end{array}$ & $\begin{array}{l}\text { Anugerahwati, } \\
\text { ada hubungan }\end{array}$ \\
\hline hasil & pengetahuan deng \\
\hline didapatkan & prefalensi \\
\hline ahwa sebagian besar & Menurut Anugerahw \\
\hline memiliki & pendidi \\
\hline ndidikan & sangat berpengar \\
\hline MP atau Sederajat & terhadap pengetahus \\
\hline banyak 16 responden & semakin \\
\hline $3,3 \%)$ & pendidikan \\
\hline kolah sebanyak SD & semakin mudah $p$ \\
\hline au sederajat sebanyak & menerima \\
\hline responden $(32,4 \%)$. & (Anugerahwati, N, 201 \\
\hline hingga dimungkinkan & Dari \\
\hline sponden memiliki & penelitian menunjukk \\
\hline ngetahuan yang baik, & Sebanyak 16 respond \\
\hline $\begin{array}{l}\text { api telaah } \\
\text { apatkan k }\end{array}$ & $\begin{array}{l}(43,3 \%) \text { sebagai } t \\
\text { bekerja atau sebagai }\end{array}$ \\
\hline ponden yang & rumah tangga den \\
\hline
\end{tabular}


kata lain menghabiskan banyak waktu dirumah mengurus keluarga yang diasumsikan memiliki banyak kesempatan dalam hal melaksanakan PSN untuk mencegah DBD yaitu melalui kegiatan pembersihan rumah dan sekitarnya dengan melaksanakan 3M. Pekerjaan seseorang berpengaruh terhadap pengetahuan dan sikap serta praktek untuk melakukan suatu tindakan, karena orang yang bekerja akan lebih banyak berinteraksi dengan dunia luar baik itu teman ataupun lingkungan sehingga orang tersebut memiliki pengetahuan ataupun karena pengalaman orang lain yang berada disekitarnya sehingga orang tersebut melakukan tindakan sebagai realisasi terhadap pengetahuan serta sikap yang tertanam di dalam dirinya (Fathi, 2005)

Pengetahuan

mengenai Demam Berdarah Dengue, vector penyebab dan faktor yang mempengaruhi

keberadaan jentik nyamuk Aedes aegypti sangat diperlukan untuk mencegah penularan penyakit DBD. Kurangnya pengetahuan dapat berpengaruh pada tindakan yang akan dilakukan karena pengetahuan

merupakan salah satu faktor predisposisi untuk berperilaku. Perilaku seseorang akan berpengaruh terhadap lingkungan. Perilaku yang diharapkan adalah upaya Pemberantasan Sarang Nyamuk (PSN).

\section{b. Sikap Keluarga Penderita Demam Berdarah Dengue} Dapat di simpulkan bahwa sikap keluarga tentang pemberantasan sarang nyamuk sebagian besar dalam kategori cukup da baik yaitu masing masing sebanyak 14 responden $(37,8 \%)$ dan 16 responden (43,3\%). Untuk lebih mendalami analisis mengenai tingkat sikap secara spesifik berdasarkan pertanyaan tentang sikap yang dijawab oleh 


\section{Riska Dewi Dian Susanti : Tingkat Pengetahuan}

\begin{tabular}{|c|c|}
\hline $\begin{array}{l}\text { responden. Hasilnya } \\
\text { adalah secara umum }\end{array}$ & $\begin{array}{llr} & \text { Hasil } & \text { penelitiar } \\
\text { ini } & \text { sesuai } & \text { dengar }\end{array}$ \\
\hline responden $\quad$ telah & penelitian \\
\hline menunjukkan sikap & dilakukan \\
\hline yang cukup baik tentang & Marni \\
\hline hal - hal yang & hubungan \\
\hline erhubungan dengan & pengetahuan dan sik \\
\hline penyakit DBD dan & dengan praktik $\mathrm{i}$ \\
\hline kegiatan & rumah tangga dala \\
\hline esponden & pemberantasan sara \\
\hline enunjukkan & nyamuk \\
\hline ng cukup baik tentang & berdarah \\
\hline haya nyamuk Aedes & Kelurahan \\
\hline bagai vektor penyakit & Kecamatan Oebobo Kc \\
\hline $\mathrm{BD}$, tentang kegiatan & Kupang, Menurut Ler \\
\hline nguras dan tentang & Marni sikap respond \\
\hline atisasi. Tingkat sikap & merupakan respon y \\
\hline sponden yang masih & masih tertutup $\mathrm{c}$ \\
\hline arang terlihat pada & tidak tampak \\
\hline gkat sikap tentang & kehidupan \\
\hline nutup, tingkat sikap & sehingga \\
\hline tang mengubur dan & mereka setuju terhad \\
\hline gkat sikap tentang & pemberantasan sar \\
\hline biasaan menggantung & nyamuk \\
\hline kaian bekas pakai. & berdarah dengue bel \\
\hline sering & melakuk \\
\hline peroleh & tindakan \\
\hline engalaman & sikapnya. \\
\hline au dari orang lain & responden \\
\hline ing paling terdekat. & pemberantasan sara \\
\hline membuat & nyamuk dem \\
\hline mendekati & berdarah dengue tic \\
\hline u menjauhi orang & disadari \\
\hline in atau objek lain, & kesadaran \\
\hline p positif terhadap & melakukan tindak \\
\hline ai-nilai kesehatan & pemberantasan sara \\
\hline ak selalu terwujud & nyamuk \\
\hline am satu & berdarah dengue. Sik \\
\hline nyata. & $\begin{array}{l}\text { belum tentu terw } \\
\text { dalam tindakan se }\end{array}$ \\
\hline
\end{tabular}


terwujudnya sebuah tindakan yaitu antara lain adanya fasilitas sarana dan prasarana.(Fathi, 2005)

c. Hubungan Tingkat Pengetahuan Dengan Sikap Keluarga

Penderita Demam Berdarah Dengue Tentang

Pemberantasan

Sarang Nyamuk

Hasil uji statistik Spearman's Rho dengan derajat kemaknaan $\mathrm{p}<$ 0,05. Didapatkan $p$ value 0,002 yang berarti Ho ditolak dan $\mathrm{H} 1$ diterima maka, Ada Hubungan Tingkat Pengetahuan Dengan Sikap Keluarga Penderita Demam Berdarah Dengue Tentang Pemberantasan Sarang Nyamuk Di Wilayah Kerja Puskesmas Curahdami dengan tingkat Correlation Coefficient 0,487.

\section{Dapat}

disimpulkan bahwa semakin tinggi tingkat pengetahuan responden maka semakin baik pula sikap responden dalam Pemberantasan Sarang
Nyamuk. (Widagdo, L., Husodo, 2018) Hal tersebut sesuai dengan penelitian terdahulu Widagdo, yang menyatakan bahwa faktor pengetahuan mempunyai hubungan yang bermakna terhadap perilaku pemberantasan sarang nyamuk.

terhadap

Tingginya sikap pemberantasan sarang nyamuk disebabkan karena motivasi dari petugas kesehatan, ketersediaan informasi tentang pemberantasan sarang nyamuk dan setiap tahun kasus demam berdarah selalu ada walaupun hasil penelitian pengetahuan responden kurang baik. Salah satu faktor yang mempengaruhi

perubahan sikap seseorang adalah komponen kognitif yang berisi kepercayaan seseorang mengenai obyek sikap. Kepercayaan datang dari apa yang kita lihat atau apa yang telah kita ketahui yang kemudian berbentuk suatu ide 


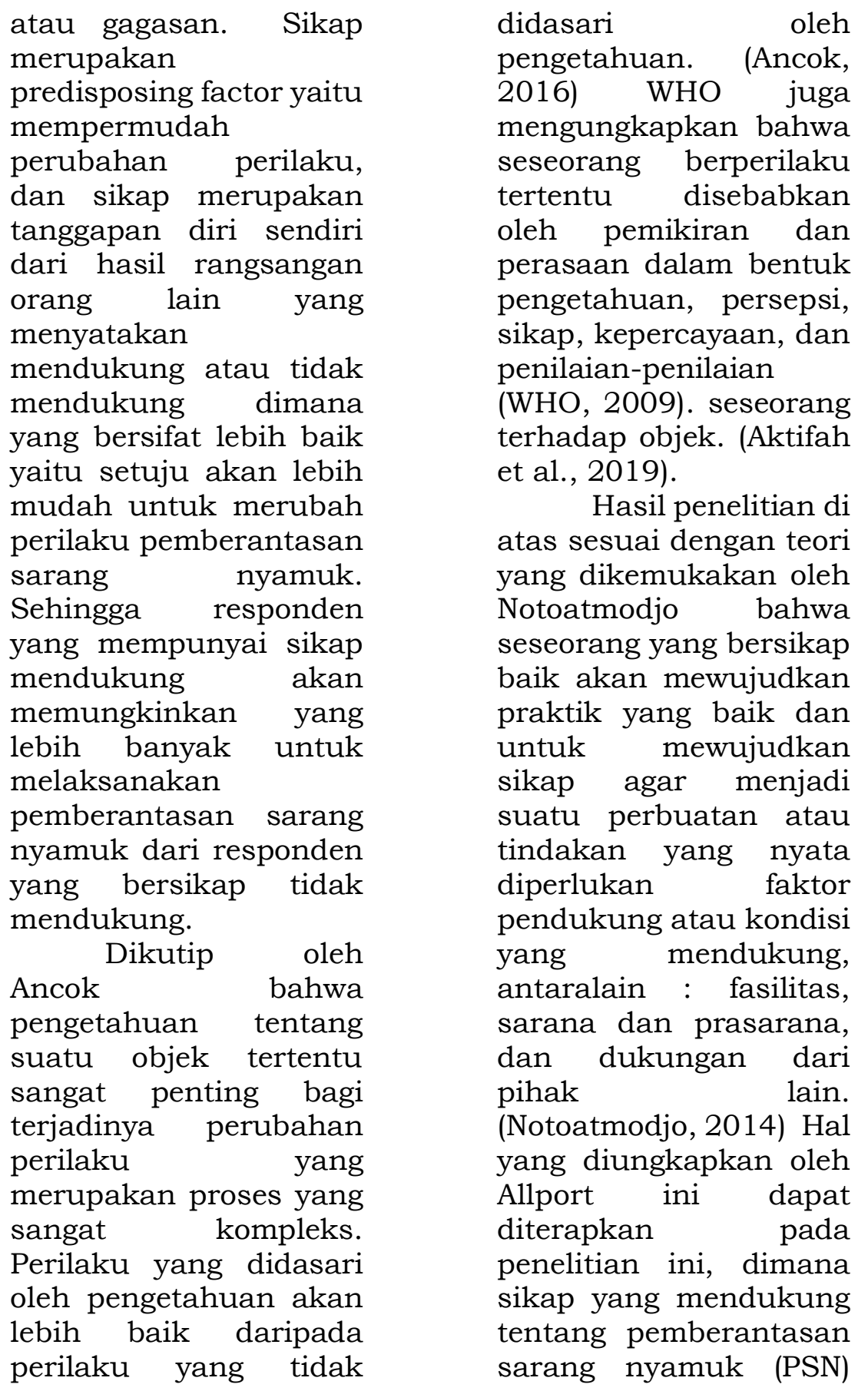




\section{Riska Dewi Dian Susanti : Tingkat Pengetahuan}

dapat meningkatkan kecenderungan untuk melakukan tindakan pencegahan penyakit demam berdarah dengue (DBD) yang pada akhirnya akan berdampak penurunan kejadian demam pada dengue (DBD).

\section{Simpulan}

Tingkat Pengetahuan Keluarga Penderita Demam Berdarah Dengue Tentang Pemberantasan Sarang Nyamuk Di Wilayah Kerja Puskesmas Curahdami adalah Baik. Sikap keluarga penderita demam berdarah Tentang Pemberantasan Sarang Nyamuk Di Wilayah Kerja Puskesmas Curahdami adalah Baik serta Hubungan Tingkat Pengetahuan Dengan Sikap Keluarga Penderita Demam Berdarah Dengue Tentang Pemberantasan Sarang Nyamuk Di Wilayah Kerja Puskesmas Curahdami adalah Baik

\section{Daftar Pustaka}

Aktifah, N., Ersila, W., Prafitri, L. D., \& Sabita, R. (2019).
Meningkatkan

kemandirian pasien pasca stroke melalui in-house training kader pendukung lansia pasca stroke. Indonesian Journal of Community Services, 1(1), 95. https://doi.org/10.30 659/ijocs. 1.1.95-104

Ancok, D. (2016). Teknik Penyusunan Skala Pengukuran. Gadjah Mada University Press. Anugerahwati, N, F. (2012). Hubungan Tingkat Pengetahuan Ibu Tentang Penyakit DHF Dengan Prevalensi DHF. Jurnal Ilmiah STIKES Hang Tuah Surabaya, Volume $3 \mathrm{~N}$. Djunaedi D. (2006). Demam Berdarah Dengue, Epidemiologi,P atogenesis,Diagnosis dan

Penatalaksanaannya. UMM Press.

Fathi, dkk. (2005). Peran Faktor Lingkungan dan Perilaku terhadap Penularan DBD di Kota Mataram. Jurnal Kesehatan

Lingkungan, Vol. 2, No. Kemenkes. (2017). Pedoman Pencegahan dan Pengendalian 


\section{Riska Dewi Dian Susanti : Tingkat Pengetahuan}

Demam Berdarah

Dengue di Indonesia.

Larasati, R. (2013).

Hubungan Kebersihan

Mulut dengan

Penyakit Sistemik dan

Usia Harapam Hidup.

Skala Husada, 9(1), 97-104.

Notoatmodjo. (2014). Ilmu

Perilaku Kesehatan,. Jakarta: PT Rineka Cipta; 115.

Rahayu et al. (2017).

Jurnal Ilmu Kesehatan

Masyarakat.

November,

Riyanto. (2010). Hubungan

Tingkat

Pendidikan,Pengetahu

an dan Sikap Ibu

Rumah Tangga Den gan Kegiatan $3 M$ Demam Berdarah

Dengue Di Puskesmas

Loa Ipuh Kabupaten

Kutai

Kartanegara.(Tesis),

Surakarta: Program

Pascasarjana

Universitas Sebelas

Maret,.

pustaka,uns.ac.id

Subdin P2PM. (2019).

Penyakit Demam

Berdarah Dengue.

Syahrani , Santoso, \&

Sayono (2012) dalam

ery wahyuni, 2015.

(2015). Hubungan
Antara Tingkat

Pengetahuan, Sikap, Dan Perilaku keluarga Tentang motivasi pemberantasan sarang nyamuk Di Wilayah Kerja Puskesmas Ngesrep Kota Semarang Tahun 2015, (F. I. K. U. N. Semarang (ed.)).

Syed, M., \& S. (2010). Knowledge, attitudes and practices regarding dengue fever among adults of high and low socioeconomic groups 60(March).

Utami, $\mathrm{K}$. (2010). Hubungan Tingkat Pendidikan Formal Terhadap Perilaku Pencegahan Demam Berdarah Dengue (DBD) Pada Masyarakat Di kelurahan

Bekonang,Sukoharjo,(

Skripsi)),

Surakarta:Fakultas

Kedokteran

Universitas Sebelas Maret.

WHO. (2009). Dengue Guidleines for Diagnosis, Tratment, $\mathrm{Pr}$ evention and Control.New Edition.Geneva: World Health Organization. 


\section{Riska Dewi Dian Susanti : Tingkat Pengetahuan}

Widagdo, L., Husodo, B. T.

\& B. (2018).

Kepadatan Jentik

Nyamuk Aedes Aegypti

Sebagai Indikator

Keberhasilan Praktek

PSN (3M Plus) Studi Di

Kelurahan Srondol

Wetan Semarang.

Makara, Kesehatan. 